\title{
Evidence for phytoplankton succession and chromatic adaptation in the Sargasso Sea during spring 1985*
}

\author{
Robert R. Bidigare ${ }^{1}$, John Marra ${ }^{2}$, Tommy D. Dickey ${ }^{3}$, Rudolfo Iturriaga ${ }^{4}$, Karen S. \\ Baker ${ }^{5}$, Raymond C. Smith ${ }^{6}$, Hasong Pak ${ }^{7}$ \\ ${ }^{1}$ Geochemical \& Environmental Research Group, Department of Oceanography, Texas A\&M University, College Station, Texas \\ 77843, USA \\ ${ }^{2}$ Lamont-Doherty Geological Observatory, Columbia University, Palisades, New York 10964, USA \\ ${ }^{3}$ Ocean Physics Group, Department of Geological Sciences, University of Southern California, Los Angeles, California 90089 , \\ USA \\ ${ }^{4}$ Department of Biological Sciences, University of Southern California, Los Angeles, California 90089, USA \\ ${ }^{5}$ University of California Marine Bio-Optics Group, Scripps Institution of Oceanography, University of California at San Diego, \\ La Jolla, California 92093, USA \\ ${ }^{6}$ University of California Marine Bio-Optics Group, University of California at Santa Barbara, Santa Barbara, California 93106 , \\ USA \\ ${ }^{7}$ Department of Oceanography, Oregon State University, Corvallis, Oregon 97331, USA
}

\begin{abstract}
Measurements of photosynthetic pigments, nutrients, spectral irradiance and various physical parameters were performed in the western Sargasso Sea $\left(35^{\circ} \mathrm{N}, 70^{\circ} \mathrm{W}\right)$ to investigate the factors affecting phytoplankton biomass distributions. Algal pigment concentrations and compositions measured during spring 1985 showed considerable time-dependent variations which were consistent with those documented by direct microscopic observation. During early April, 2 -fold increases in chlorophyll a and fucoxanthin were measured on a relatively short time scale of days. The presence of a diatom-dominated community, mainly species of the genera Rhizosolenia and Chaetoceros, suggested that we were witnessing a stage of the spring bloom. Upon return to this location 2 wk later, the diatom bloom was replaced by a considerably more diverse phytoplankton assemblage consisting of prymnesiophytes, cyanobacteria, dinoflagellates, green algae (including prasinophytes) and diatoms. The vertical structures displayed by individual accessory pigments during April were markedly similar and suggest that the major phytoplankton taxa were not uniformly distributed in the upper $200 \mathrm{~m}$. The phytoplankton were distributed as broadly overlapping layers, with cyanobacteria and diatoms most abundant in the mixed layer, prymnesiophytes at intermediate depths, and green algae (including prasinophytes) deeper in the water column. Results provide descriptive evidence for a rapid succession of chromatically-adapted phytoplankton during springtime in the Sargasso Sea.
\end{abstract}

\section{INTRODUCTION}

A current objective of biological oceanography is to quantify the mean and variance of phytoplankton biomass and production on basin-wide and global scales (e.g. U.S. Global Ocean Flux Study [GOFS], National Academy of Sciences 1984). For the North Atlantic Ocean, there is a strong seasonality associated with these parameters which has been attributed to the availability of nutrients and radiant energy (Menzel \&

\footnotetext{
- Biowatt contribution no. 31
}

Ryther 1960, 1961, Brown et al. 1985, Feldman et al. 1989). During winter, deep convective mixing processes replenish near-surface nutrients depleted by phytoplankton during the previous season. Increases in photosynthetically active radiation (PAR) and water column stability by the input of solar radiation during spring make conditions favorable for the annual 'spring bloom' of phytoplankton. The spring bloom of the North Atlantic typically occurs in April; however, the exact timing and magnitude of the bloom varies interannually and episodically (Menzel \& Ryther 1960. 1961, Deuser 1986). For this reason, little is known of 
the composition of the phytoplankton which contribute to this bloom and how it changes with respect to time and depth.

The distributions and growth rates of the major algal groups representing marine phytoplankton are primarily controlled by the availability of nutrients and radiant energy. The fluxes of these rate-limiting factors are, in turn, governed by the physical, biological and optical properties of the water column. Ultimately, a detailed understanding of the interactions among these processes will lead to the formulation of models which predict biological distributions and rate processes from remotely-sensed optical parameters (ct. Bidigare et al. 1987, Smith et al. 1987a, 1989). Toward this objective, the U.S. Office of Naval Research (ONR) sponsored a 5 yr program, Biowatt, to define the causal links between physical, biological and optical processes in the upper ocean. Complete details of this program have been described by Marra \& Hartwig (1984).

During the first field year of the Biowatt program, a series of bio-optical and physical measurements were performed during spring (2 to 28 April 1985) in the northwestern Atlantic Ocean. By choosing the spring season, it was possible to observe large changes in phytoplankton biomass and composition on time scales of days-to-weeks, against a background of increasing stratification within the euphotic zone (cf. Bidigare et al. 1989a, Marra et al. 1989). We present here a descriptive suite of observations taken at a single location $\left(35^{\circ} \mathrm{N}, 70^{\circ} \mathrm{W}\right)$ which provides evidence for a relatively rapid succession of chromatically-adapted phytoplankton in the Sargasso Sea.

\section{MATERIALS AND METHODS}

Study site. All measurements were made aboard the RV 'Knorr' in the vicinity of a drifting buoy which supported the multi-variable profiler (Dickey et al. 1986, Dickey 1988). Stns 4 and 19 were both located at $35^{\circ} \mathrm{N}, 70^{\circ} \mathrm{W}$ and were occupied during 3 to 7 April and 19 to 25 April 1985, respectively.

Meteorological measurements. Wind-speed, total downwelling irradiance ( $E_{\text {tot }} ; 285$ to $2800 \mathrm{~nm}$ from an Eppley hemispherical pyranometer) and UV irradiance (290 to $385 \mathrm{~nm}$ ) were recorded at 1 min intervals from atop the forward superstructure of the ship. Downwelling spectral irradiance, $E(\lambda)$ (at wavelengths of 410 , $441,465,488,520,540,560,589,625,671$, and $694 \mathrm{~nm}$ ). was simultaneously recorded during casts of the biooptical profiler (see below)

Physical and chemical measurements. Hydrographic measurements were performed with a conductivitytemperature-depth (CTD) profiler. The CTD was equipped with an in situ fluorometer and a 12-bottle rosette sampler for seawater collection. The system provided a real-time display of selected vertical profiles, including fluorescence and irradiance, so that features within the water column could be identified during the down-cast for sampling during the up-cast. Hydrographic measurements and water samples were also acquired with the bio-optical profiler as described below.

The autonomous multi-variable profiler (MVP; Dickey 1988) was tethered to a surface drifter which was followed during the observations. The position of the drifter was determined to provide Lagrangian current information. The MVP made hourly profiles through the upper 200 to $250 \mathrm{~m}$ of the water column using helium as a buoyancy medium. Data taken by the MVP included: temperature, conductivity, photosynthetically available radiation (PAR; 400 to $700 \mathrm{~nm}$ ) and horizontal currents. Data were recorded internaliy on magnetic tape and transmitted back to the RV 'Knorr' for real-time data display.

Nutrient analyses were performed with a 6-channel Alpkem rapid-flow analyzer. Nitrate was determined using the method described by Whitledge et al. (1981).

Optical properties. Continuous optical profiles were made using a Bio-optical Profiling System (BOPS; Smith et al. 1984). The BOPS consists of an abovewater deck unit, an underwater package with 2 (upward and downward looking) spectral irradiance units (MER-1015, Biospherical Instruments, Inc.), and a rosette sampler equipped with ten 1.7 l Niskin bottles. BOPS also includes sensors for the determination of depth, beam transmittance at $665 \mathrm{~nm}$ (Bartz et al. 1978), temperature, conductivity, PAR and in situ fluorescence. The BOPS was lowered from the port quarter of the ship which was positioned so that its axis was normal (port-side) to the sun's azimuth.

Analyses of particulates. Coccoid cyanobacteria and small autotrophic/heterotrophic flagellates were enumerated using the epifluorescence microscopic techniques of Hobbie et al. (1977) and Caron (1983). Autotrophs were visualized by using a band-pass excitation filter ( 450 to $490 \mathrm{~nm}$ ) and a $528 \mathrm{~nm}$ barrier filter combination. Heterotrophs were stained with primulin (Caron 1983), and visualized with a UV excitation filter (340 to $380 \mathrm{~nm}$ ) and a $418 \mathrm{~nm}$ barrier filter combination. At selected stations, water samples were preserved with Lugol's solution, for enumeration of phytoplankton by the Utermöhl method.

Chlorophyll a and phaeopigment concentration (ug $\left.1^{-1}\right)$ were routinely determined by the method of Smith et al. (1981) Fluorescence readings were performed with a Tumer Model 111 fluorometer which was calibrated periodically during the cruise with chlorophyll a (Sigma Chemical Co.) as a reference standard 
The particle size distributions were determined using a resistive-pulse Coulter Counter equipped with 50 and $100 \mu \mathrm{m}$ apertures. With the smaller aperture, particles between 2.0 and $12.5 \mu \mathrm{m}$ spherical equivalent diameters were counted. The larger aperture enabled particles between 3.1 and $25 \mu \mathrm{m}$ to be counted. For data analysis, the particle counts were summed within data windows, each of which covered particles with volumes between consecutive half powers of $2 \mathrm{\mu m}^{3}$.

HPLC pigment analysis. Photosynthetic pigments were analysed at sea by high-performance liquid chromatography. Water samples (11) were filtered through $0.4 \mu \mathrm{m}$ polyester Nuclepore filters $(47 \mathrm{~mm}$ ) and extracted in $90 \%$ acetone at $-20^{\circ} \mathrm{C}$ for 24 to $48 \mathrm{~h}$. Following extraction, the samples were centrifuged for $5 \mathrm{~min}$ to remove cellular debris. Chlorophyll and carotenoid pigments were separated using a SpectraPhysics Model SP8100 liquid chromatograph and Radial-PAK $\mathrm{C}_{18}$ column $(0.8 \times 10 \mathrm{~cm}, 10 \mu \mathrm{m}$ particle size; Waters Assoc.) at a flow rate of $10 \mathrm{ml} \mathrm{min-1.}$ Samples were prepared for injection according to the method outlined by Mantoura \& Llewellyn (1983). A 2step solvent program was used to separate the acetoneextractable phytoplankton pigments (Hooks et al. 1988). After injection (500 ul sample), mobile phase $A$ (80:15:5; methanol: water: iron-pairing agent) was ramped to mobile phase $B$ (methanol) over a $12 \mathrm{~min}$ period. Mobile phase B was then pumped for 13 min for a total analysis time of $25 \mathrm{~min}$.

Individual peaks were detected and quantified (by area) with a Waters Model 440 Fixed Wavelength Detector (436 $\mathrm{nm}$ ) and a Hewlett-Packard Model 3392A integrator. The specific algal pigments identified and quantified during the cruise include: chlorophylis $a, b$ and $c$; chlorophyllide $a$; peridinin; fucoxanthin; 19'-hexanoyloxyfucoxanthin; prasinoxanthin; diadinoxanthin; zeaxanthin (plus lutein); and $\beta, \beta$ carotene. Details of instrument calibration and peak identification are given in Hooks et al. (1988). The HPLC method employed is not capable of separating zeaxanthin from lutein and we have assumed that this peak is dominated by zeaxanthin as suggested by subsequent pigment observations in the Sargasso Sea (Bidigare unpubl., R. Goericke pers. comm.). As primary taxonomic markers (Jeffrey 1974, Norgard et al. 1974, Jeffrey 1980, Foss et al. 1984, Guillard et al. 1985, Hooks et al. 1988, Bidigare 1989), fucoxanthin, peridinin, prasinoxanthin, zeaxanthin, 19'-hexanoyloxyfucoxanthin and chlorophyll $b$ indicate the presence of diatoms, photosynthetic dinoflagellates, prasinophytes, coccoid cyanobacteria, prymnesiophytes and 'green' algae, respectively.

Photosynthetic pigment data (0 to $200 \mathrm{~m}$ ) were grouped into 3 subsets and analyzed separately: (1) Stn 4A (early-bloom, 3 to 5 April 1985); (2) Stn 4B (bloom,
6 to 7 April 1985); and (3) Stn 19 (post-bloom, 19 to 24 April 1985). The rationale for grouping data in this fashion was not arbitrary and will be discussed in greater detail below. Individual pigment concentrations determined from casts performed during each time interval were combined, interpolated (SAS Institute Inc., Cary, North Carolina) and digitized at $5 \mathrm{~m}$ intervals. In order to compare 'average' pigment abundances for each time interval, the digitized profiles were integrated with respect to depth $(0$ to $200 \mathrm{~m})$ and expressed as mg pigment $\mathrm{m}^{-2}$. Accessory pigment-tochlorophyll a ratios (w:w) were then calculated for these integrated pigment data to examine compositional changes (with respect to chlorophyll a) over time.

Rate parameters. Specific algal growth rates were measured at $\operatorname{Stn} 19$ (cast 37 ) by the ${ }^{14} \mathrm{Clabeling}$ technique of Redalje \& Laws (1981). Water samples were collected from depths corresponding to the 29, 10 and $2 \%$ light levels. Incubations with $\mathrm{NaH}^{14} \mathrm{CO}_{3}\left(100 \mu \mathrm{Ci} 1^{-1}\right)$ were performed for $24 \mathrm{~h}$ (sunrise-sunrise) in acid-washed $4 \mathrm{l}$ polycarbonate bottles. As much care as possible was taken to avoid contamination of the samples during sampling and incubation, although a completely 'clean' protocol (Fitzwater et al. 1982) could not be attained. The ${ }^{14} \mathrm{C}$ stock was cleansed of trace metals, and stored in a teflon bottle. The incubation bottles were placed in deckmounted, water-jacketed incubator boxes constructed of blue plexiglass to simulate in situ light and temperature conditions. Neutral-density screening was used to simulate the in situ light intensity. Following incubation, duplicate water samples were filtered through $25 \mathrm{~mm}$ Whatman GF/F filters for the ${ }^{14} \mathrm{C}$ assays of particulate matter (Strickland \& Parsons 1972) and chlorophyll a. ${ }^{14} \mathrm{C}$-labeled chlorophyll a was separated by HPLC and quantified by peak area. The chlorophyll a fraction purified by this technique was shown to be spectrally pure' by UV/visible diode-array spectroscopy. The $\mathrm{MeOH}$ quenching effect was compensated for by the use of an internal standard (Radiometric Instruments and Chemical Co., Inc.). Specific growth rates and related parameters were calculated using the equations given by Welschmeyer \& Lorenzen (1984).

\section{RESULTS}

\section{Hydrographic setting}

The fact that the sampling performed in this study was limited with respect to space and time makes it difficult to extrapolate results beyond spatial and temporal scales of tens-of-kilometers and hours-todays, respectively. In order to establish a framework for the interpretation of results presented below, a brief summary of Coastal Zone Color Scanner (CZCS. 
sea-surface chlorophyll) and Advanced Very High Resolution Radiometer (AVHRR, sea-surface temperature) imagery data collected over the course of this study will be given. More details as well as representative images will be presented elsewhere (Siegel et al. unpubl.).

Ten CZCS images of the study area for the time between 28 March and 28 April 1985 were processed using the standard Miami CZCS algorithm and provided valuable information regarding the timing, magnitude and areal extent of the phytoplankton bloom. It should be noted that the CZCS only provides quantitative chlorophyll information for the upper attenuation length $(37 \%$ light level) of the water column. The chlorophyll concentration at $35^{\circ} \mathrm{N}, 70^{\circ} \mathrm{W}$ on 28 March was ca $0.2 \mathrm{mg} \mathrm{m}^{-3}$ and probably represents pre-bloom conditions. Between 29 and 30 March, chlorophyll concentrations steadily increased (bloom initiation) and reached maximum values of 0.5 to $0.6 \mathrm{mg} \mathrm{m}^{-3}$ during the period when Stn 4 was occupied (3 to 7 April). The phytoplankton bloom event witnessed at Stn 4 had a
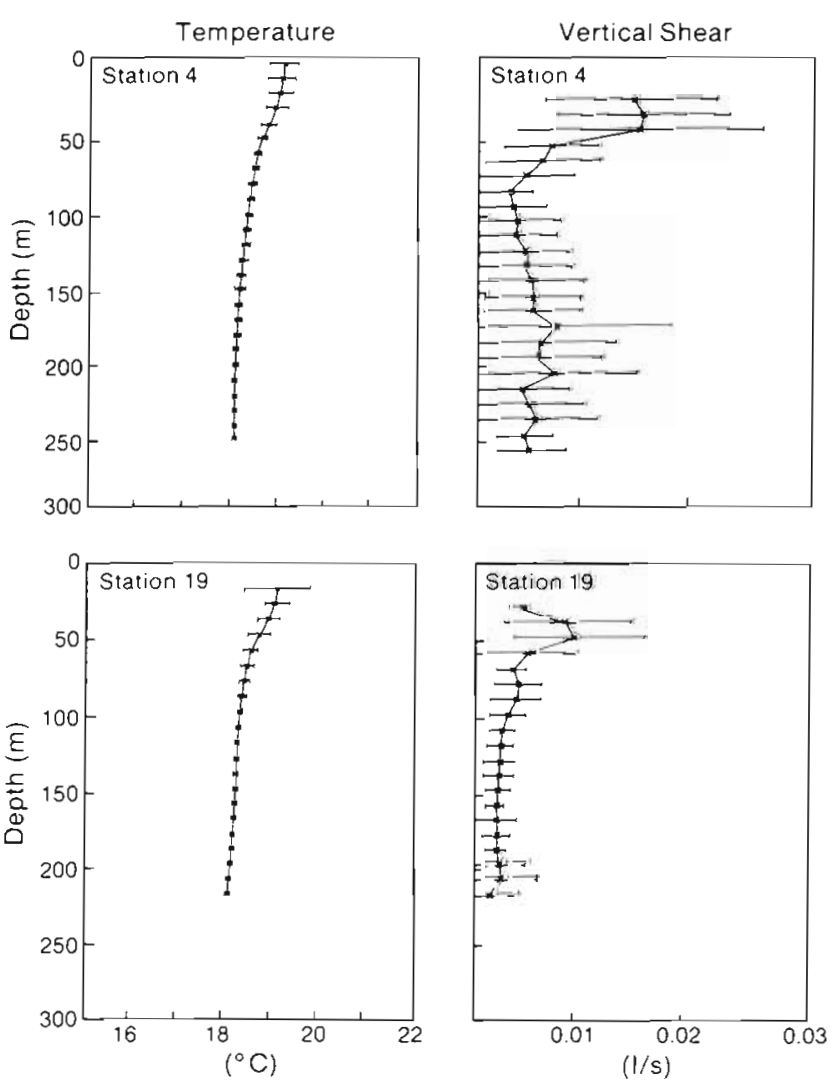

Fig. 1. Vertical profiles of mean temperature and vertical shear of horizontal current profiles measured with the multiple variable profiler (MVP) at Stns 4 and 19. Error bars indicate $95 \%$ confidence intervals large areal extent with a horizontal spatial scale of ca $500 \mathrm{~km}$. During 8 to 9 April chlorophyll concentrations began to decline and reached pre-bloom levels on 11 April. Between 11 and 28 April, near-surface chlorophyll concentrations remained constant and values ranged from 0.15 to $0.20 \mathrm{mg} \mathrm{m}^{-3}$. HPLC-determined chlorophyli a concentrations were consistent with those estimated by satellite imagery and were within the $40 \%$ tolerance expected for this region (Smith et al. $1987 \mathrm{~b})$.

Sea-surface temperatures were uniform in the vicinity of the sampling location $\left(35^{\circ} \mathrm{N}, 70^{\circ} \mathrm{W}\right)$ with values averaging ca $19^{\circ} \mathrm{C}$. There was no evidence provided by the thermal imagery data to suggest that cold core eddies or Gulf Stream meanders influenced measurements performed at $35^{\circ} \mathrm{N}, 70^{\circ} \mathrm{W}$ during the study period.

\section{Hydrographic measurements and spectral irradiance distributions}

The vertical temperature structure was similar for Stns 4 and 19 (Fig. 1); however, considerably more variance in near-surface temperatures was observed for Stn 19. This was primarily caused by near-surface heating which was more pronounced during Stn 19. Time-series measurements of temperature and vertical shear (of the horizontal currents) collected with the MVP (Dickey et al. 1986) indicate a near-surface warming trend and increased stratification, both of which are characteristic of the spring transition. The increased water column stability observed upon return to $35^{\circ} \mathrm{N}$, $70^{\circ} \mathrm{W}$ (Stn 19) is also reflected in the mean profile of vertical shear (Fig. 1).

Approximately $12 \mathrm{~d}$ elapsed between the end of Stn 4 and the commencement of Stn 19. The weather at $35^{\circ} \mathrm{N}, 70^{\circ} \mathrm{W}$ during this period was moderate with no significant frontal passages, either fair or partly cloudy skies, and generally light winds $\left(<7 \mathrm{~m} \mathrm{~s}^{-1}\right)$. It is likely that the temporary episodes of cooling and reduced stratification observed during $\operatorname{Stn} 4$ retarded the spring transition. This, however, is probably an important mechanism for entraining nutrients needed for increased biological productivity. While nitrate concentrations in surface waters of Stns 4 and 19 were below the limit of detection, the depth of the nitracline had deepened considerably upon return to $35^{\circ} \mathrm{N}, 70^{\circ} \mathrm{W}$ (Fig. 2)

Distributions of spectral irradiance $(400$ to $700 \mathrm{~nm}$ ) measured at Stns 4 and 19 also showed considerable differences (Fig. 3). This was most apparent for the blue-green wavelengths of light, whose depths of penetration increased significantly upon return to this location. 


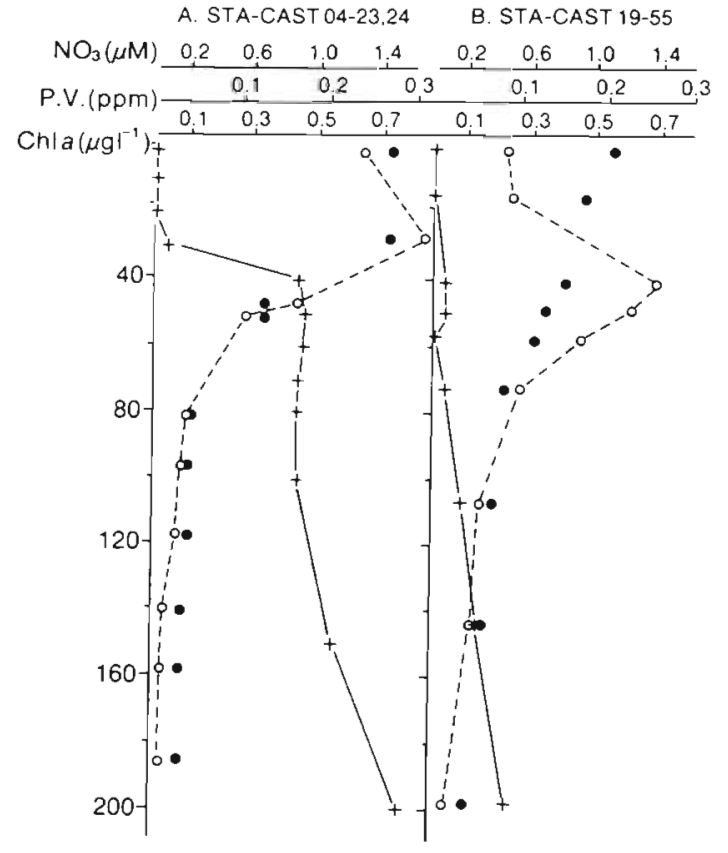

Fig. 2. Representative profiles of nitrate concentration $(+)$; Coulter Counter-determined particle volume (P.V.) for particles $>2 \mu \mathrm{m}(\bullet)$; and fluorometrically-determined chlorophyll a concentration (O) measured at (A) Stn 4 and (B) Stn 19

Particle, phytoplankton and pigment distributions at Stn 4

For Stn 4, particle volumes closely followed chlorophyll a distributions throughout the upper $200 \mathrm{~m}$ (Fig. 2). The presence of a diatom-dominated community, mainly species of the genera Rhizosolenia and Chaetoceros (F. Reid pers. comm.), suggests that we were witnessing a stage of the spring bloom. There were relatively few flagellate forms or cyanobacteria seen in the microscope preparations (data not shown) and this evidence was reinforced by the accessory pigment data presented below.

The dominant accessory pigment measured at Stn 4 was fucoxanthin (Table 1), confirming the microscopic observations which revealed that diatoms were a major biomass component in the upper $50 \mathrm{~m}$. In contrast, concentrations of $19^{\prime}$-hexanoyloxyfucoxanthin (prymnesiophytes), chlorophyll $b$ (green algae), prasinoxanthin (prasinophytes), peridinin (dinoflagellates) and zeaxanthin (cyanobacteria) were considerably lower. Unfortunately, no HPLC pigment data are available for the period prior to the bloom which initiated between 29 and 30 March 1985 (see above). One week following the onset of the bloom (Stn 4A; Fig. 4), a weak subsurface chlorophyll a maximum was located at ca $25 \mathrm{~m}$. During the peak of the bloom (Stn 4B; Fig. 5), the chlorophyll a content of the upper $200 \mathrm{~m}$ increased $>2$ - fold (relative to early bloom conditions) and its depth of maximum concentration deepened to ca $50 \mathrm{~m}$. Parallel increases in fucoxanthin indicate that the bloom was caused by diatoms which 'diluted-out' the already low background populations of cyanobacteria, green algae (including prasinophytes), prymnesiophytes and dinoflagellates (see accessory pigment-to-chlorophyll a ratios in Table 1).

\section{Particle, phytoplankton and pigment distributions at Stn 19}

Upon return to this location (Stn 19), the depth of the chlorophyll maximum was located at ca $45 \mathrm{~m}$. In contrast to Stn 4 , the vertical profiles of particle volume and chlorophyll a exhibited considerably different structures in the upper $60 \mathrm{~m}$ (Fig. 2). This, however, is not surprising since the measurement of particle volume was limited to particles of $>2 \mu \mathrm{m}$ equivalent spherical diameter and the dominant autotrophs were in the range of 0.5 to $1.2 \mu \mathrm{m}$ (Iturriaga \& Marra 1988),
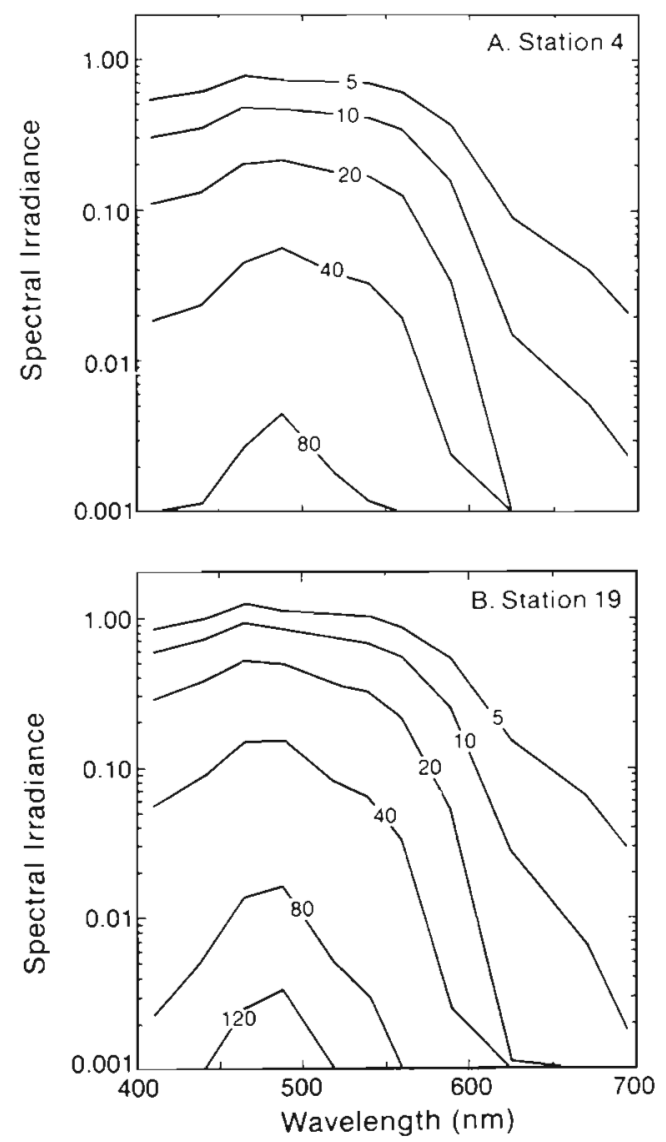

Fig. 3. Spectral irradiance distributions for selected depths at (A) Stn 4 and (B) Stn 19. Data are given as the fraction of surface irradiance and were collected with the bio-optical profiling system (BOPS) 
Table 1. Integrated HPLC-determined pigment concentrations ( $\mathrm{mg} \mathrm{m} \mathrm{m}^{-2}, 0$ to $200 \mathrm{~m}$ ) and accessory pigment-tochlorophyll a ratios ( $w: w$ ) for Stn $4 A$ (early-bloom), Stn $4 B$ (bloom) and Stn 19 (post-bloom)

\begin{tabular}{|lrrr|}
\hline Parameter & Stn 4A & Stn 4B & Stn 19 \\
\hline Pigment concentration $\left(\mathrm{mg} \mathrm{m}^{-2}\right.$ ) & & & \\
Chlorophyll a & 38.58 & 85.00 & 41.27 \\
Chlorophyll $b$ & 5.86 & 6.67 & 9.01 \\
Chlorophyld $c$ & 5.64 & 7.48 & 3.28 \\
Fucoxanthin & 20.34 & 54.86 & 9.51 \\
19'-Hexanoyloxyfucoxanthin & 9.80 & 9.23 & 15.61 \\
Zeaxanthin & 1.06 & 0.97 & 2.50 \\
Prasinoxanthin & 0.30 & 0.13 & 1.10 \\
Peridinin & $<0.01$ & 0.06 & 0.21 \\
Pigment ratios (w: w) & & & \\
Chl b:Chl a & 0.15 & 0.08 & 0.22 \\
Chl c: Chl a & 0.15 & 0.09 & 0.08 \\
Fucox:Chl a & 0.53 & 0.64 & 0.23 \\
Hex-fucox:Chl a & 0.25 & 0.11 & 0.38 \\
Zeax:Chl a & 0.03 & 0.01 & 0.06 \\
Pras:Chl a & 0.01 & $<0.01$ & 0.03 \\
Per:Chl a & $<0.01$ & $<0.01$ & 0.01 \\
\hline
\end{tabular}

In the 2 wk interval between occupying this location, the diatom-dominated community in the upper water column had been replaced by a cyanobacteria-dominated community. Dinoflagellate-containing colonial radiolarians were also observed in abundance at the sea surface (Latz et al. 1987). Coccoid cyanobacteria were most abundant in the mixed layer (the upper $40 \mathrm{~m}$ ) and averaged 2 to $4 \times 10^{4}$ cells $\mathrm{ml}^{-1}$ in nearsurface waters (Fig. 6). Their numbers increased slightly down to $40 \mathrm{~m}$ and declined dramatically below. At greater depths, phototrophic nanoplankton (including prymnesiophytes, chrysophytes and prasinophytes) became increasingly more abundant with a maximum located near $50 \mathrm{~m}$, ca $10 \mathrm{~m}$ deeper than the cyanobacteria maximum. While phototrophic nanoplankton were only about $10 \%$ as abundant as cyanobacteria, their cellular chlorophyll a content is 30 to 75 -fold greater than that measured for the cyanobacteria (Glover et al. 1987). Thus, at minimum, a 2-layer structure in the distribution of major autotrophs existed. The cyanobacteria counts are consistent with the values reported by Murphy \& Haugen (1985), although the abundances of phototrophic nanoplankton observed are somewhat less.

The shift in phytoplankton composition was reflected in the photosynthetic pigment content measured in the upper $200 \mathrm{~m}$ (Table 1). While the vertical structure displayed by individual accessory pigments at Stns $4 \mathrm{~B}$ and 19 were quite similar, the concentrations of accessory pigments were markedly different (Figs. 5 and 7 ). This apparent succession of the phytoplankton community is best illustrated in the accessory pigment-tochlorophyll a ratios calculated for Stns 4B and 19 (Table 1). The fucoxanthin-to-chlorophyll a ratio for Stn 19 was ca 3 -fold lower than that of Stn $4 \mathrm{~B}$. Conversely, the ratios of 19'-hexanoyloxyfucoxanthin-, zeaxanthin-, peridinin-, chlorophyll $b$-, and prasinoxanthin-to-chlorophyll $a$ all displayed $\geq 3$-fold increases. Zeaxanthin concentrations measured at Stn 19 (Fig. 7) tracked the distributions of cyanobacteria in the upper $140 \mathrm{~m}$ (Fig. 6).

\section{Phytoplankton growth rates (Stn 19)}

The highest phytoplankton carbon and chlorophyll a concentrations occurred at 15 and $44 \mathrm{~m}$, respectively, and carbon-to-chlorophyll ratios (w:w) ranged from 10 to 91 (Table 2). The depths of the phytoplankton carbon and chlorophyll a maxima agreed well with those

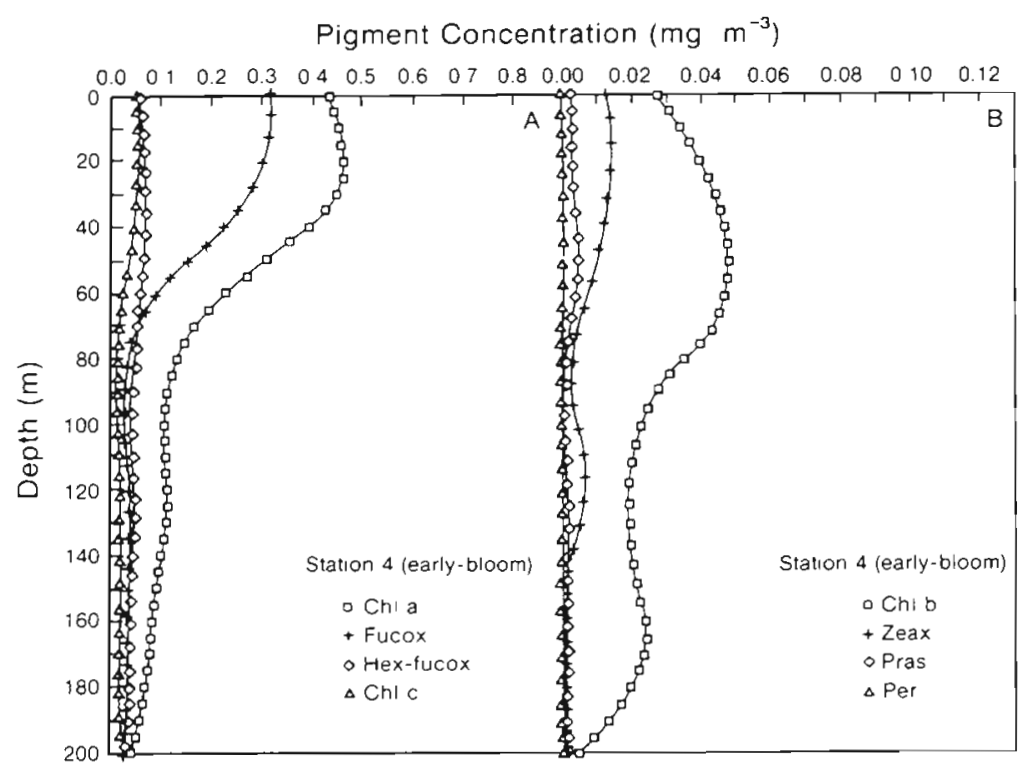

Fig. 4. Distributions of HPLC-determined phytoplankton pigment concentrations $\left(\mathrm{mg} \mathrm{m}^{-3}\right)$ at $\mathrm{Stn}$ 4A (early-bloom; casts 1, 9, 14, 24 and 26). (A) Chlorophyll a (Chl a), fucoxanthin (Fucox), 19' hexanoyloxyfucoxanthin (Hex-fucox) and chlorophyll $c$ (Chl $c)_{i}(\mathrm{~B})$ chlorophyll $b(\mathrm{Chl} b)$, zeaxanthin (Zeax), prasinoxanthin (Pras) and peridinin (Per) 


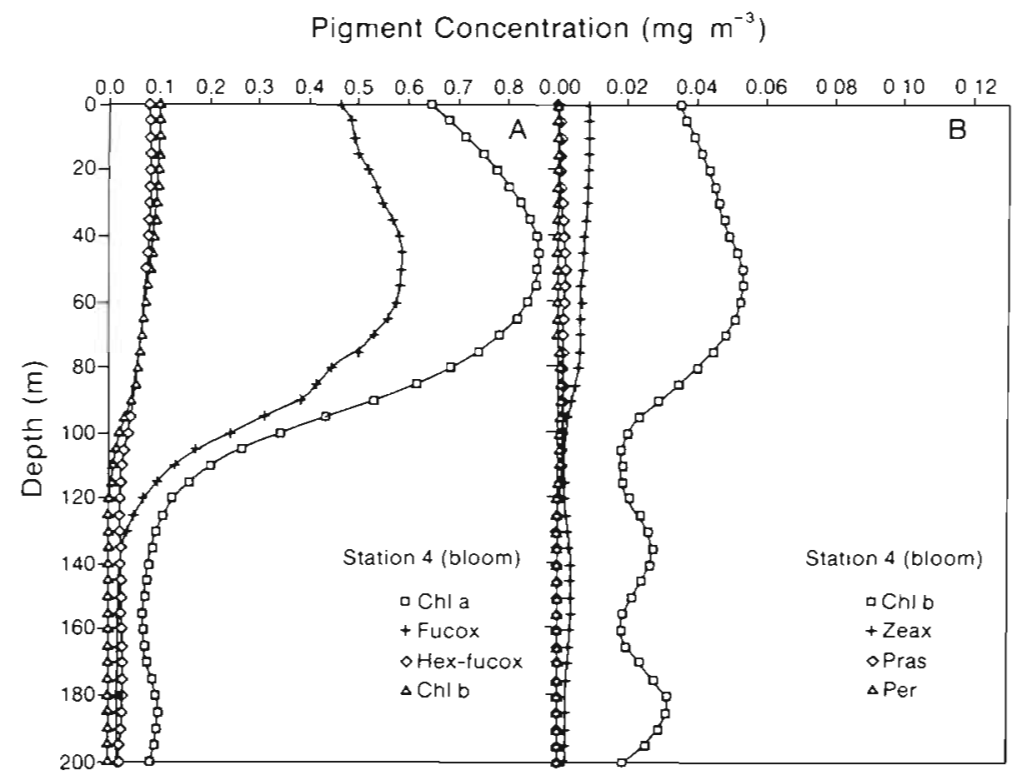

Fig. 5. Distributions of HPLC-determined phytoplankton pigment concentrations $\left(\mathrm{mg} \mathrm{m}^{-3}\right)$ at Stn $4 \mathrm{~B}$ (bloom; casts 36, 39, 45 and 47). (A) Chlorophyll a (Chl a), fucoxanthin (Fucox), 19'hexanoyloxyfucoxanthin (Hex-fucox) and chlorophyll $c(\mathrm{Chl} c)$; (B) chlorophyll b (Chl b), zeaxanthin (Zeax), prasinoxanthin (Pras) and peridinin (Per)

observed in the profiles of beam attenuation and fluorescence, respectively (data not shown). Specific growth rates varied from 0.5 to $1.4 \mathrm{~d}^{-1}$ and these values are consistent with those reported for oligotrophic waters off Hawaii (Bienfang \& Takahashi 1983, Laws et al. 1984). The highest phytoplankton growth rate was measured at a depth of $44 \mathrm{~m}$. By comparison, Iturriaga \& Marra (1988) found that cyanobacteria growth rates generally increased with increasing depth in the upper water column of Stn 19, with values in the range of 0.5 to $1.2 \mathrm{~d}^{-1}$. The rates of chlorophyll a synthesis varied from 0.086 to $0.604 \mathrm{mg} \mathrm{m}^{-3} \mathrm{~d}^{-1}$ and correspond to chlorophyll a residence times of 1 to $4 \mathrm{~d}$ (assuming steady-state conditions).

\section{DISCUSSION}

Microscopy is often limited in that ultraphytoplanktonic populations, because of their small size, cannot be easily identified beyond trophic designations. Plant pigment determinations and immunofluorescence techniques have been used as alternative means of characterizing marine phytoplankton (Campbell et al. 1983, Campbell \& Iturriaga 1988, Hooks et al. 1988, Bidigare 1989, Shapiro et al. 1989). Concentrations of photosynthetic pigments in the marine environment are primarily dependent on the species composition and photo-adaptive state of the phytoplankton present. For these reasons, accessory chlorophyll and carotenoid pigments have been used as diagnostic 'biomarkers' for investigating the distributions and light histories of marine autotrophs (Gieskes \& Kraay 1986a, b, Bidigare et al. 1987, Smith et al. 1987a, Gieskes et al. 1988, Hooks et al. 1988, Whitledge et al. 1988, Bidigare

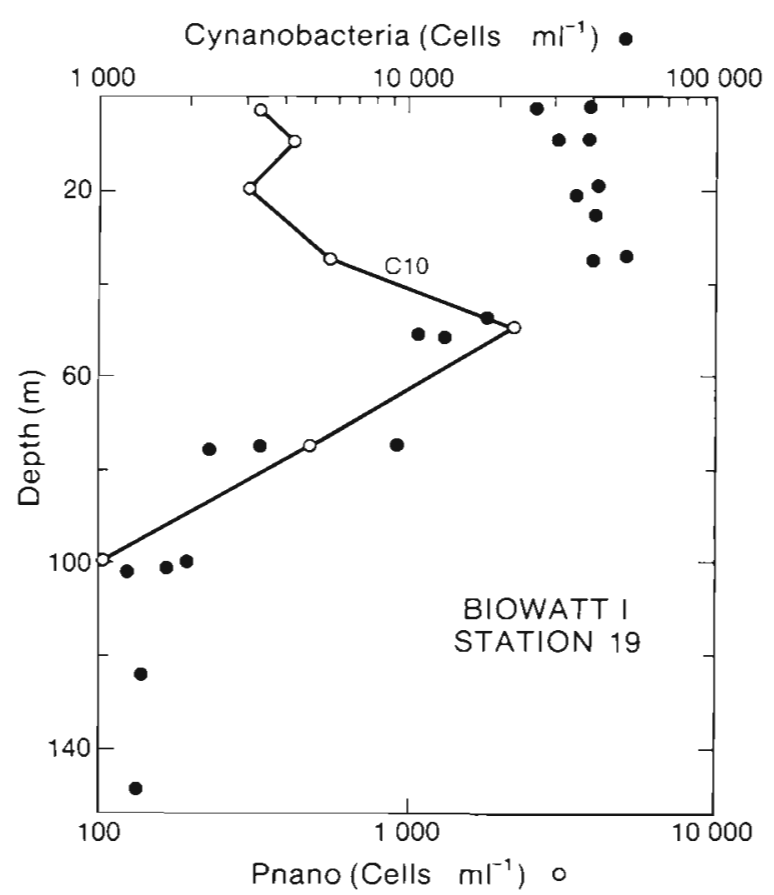

Fig. 6. Distributions of cyanobacteria $(\bullet)$ and phototrophic nanoplankton (Pnano; o) measured microscopically at Stn 19. The cyanobacteria data are a composite of 3 casts and the

Pnano data were obtained from cast 10 (C10, solid line)

et al. 1989a). Photosynthetic pigment data can, in general, be used to classify phytoplankton to the 'class' level (Hooks et al. 1988). The limitations of this chemotaxonomic approach for phytoplankton characterization have been discussed elsewhere (Hooks et al. 1988, Stauber \& Jeffrey 1988, Bidigare 1989).

Phytoplankton pigment concentrations and compositions showed considerable time-dependent variations 


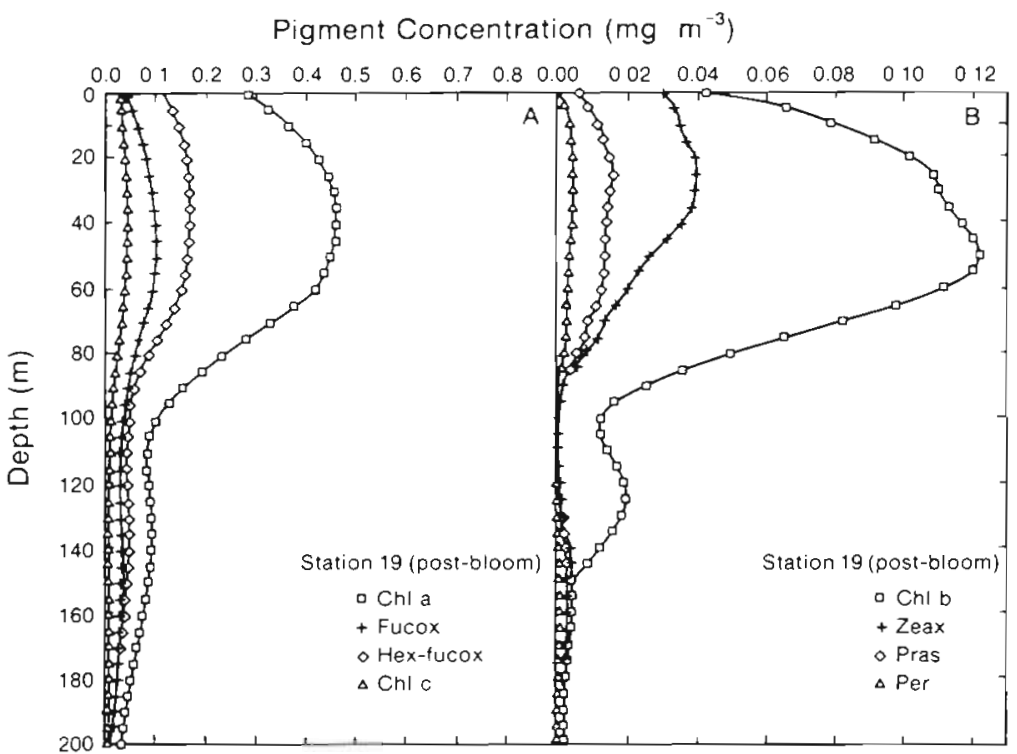

Fig. 7. Distributions of HPLC-determined phytoplankton pigment concentrations $\left(\mathrm{mg} \mathrm{m}^{-3}\right)$ at Stn 19 (post-bloom; casts 12, 21, 27 and 85). (A) Chlorophyll a (Chl a), fucoxanthin (Fucox), 19'hexanoyloxyfucoxanthin (Hex-fucox) and chlorophyll $c(\mathrm{Chl} \mathrm{C})$; (B) chlorophyll $b$ (ChI b), zeaxanthin (Zeax), prasinoxanthin (Pras) and peridinin (Per) in the western Sargasso Sea during April 1985. These results suggest that the diatom bloom observed at Stn 4 was replaced by a considerably more diverse phytoplankton assemblage consisting of prymnesiophytes, cyanobacteria, dinoflagellates, green algae (including prasinophytes) and diatoms.

The vertical structure displayed by individual accessory pigments at Stns 4 and 19 were strikingly similar and suggest that the major phytoplankton taxa were not uniformly distributed in the upper $200 \mathrm{~m}$ (Figs, 4, 5 and 7). The phytoplankton appear to have been distributed as broadly overlapping layers, with cyanobacteria and diatoms most abundant in the mixed layer, prymnesiophytes at intermediate depths, and green algae (including prasinophytes) deeper in the water column. The in vivo absorption maxima of the photosynthetic accessory pigments present in these algal groups (Bidigare et al. 1987, Bidigare et al. 1989a, b) follow the distributions of spectral irradiance measured during the cruise (Fig. 3), and are highly suggestive of a chromatically-adapted phytoplankton assemblage within the euphotic zone. Specifically, cyanobacteria (PUB-rich phycoerythrin) and diatoms (fucoxanthin); prymnesiophytes $\left(19^{\prime}\right.$-hexanoyloxyfucoxanthin and chlorophyll c-like pigments); and green algae (chlorophyll $b$ and possibly prasinoxanthin) absorb light efficiently at the blue to green, blue-green and blue wavelengths of light, respectively, which predominate at these depths.

In contrast, Lewis et al. $(1985,1986)$ were unable to detect the absorption signatures of PEB-rich cyanobacteria during the spring bloom in the Sargasso Sea and concluded that they contributed little to absorption and photosynthesis. However, it has been shown recently that cyanobacteria sampled from the Sargasso Sea are in fact PUB-rich and do not display the absorption properties characteristic of PEB-rich coastal forms (Campbell \& Iturriaga 1988, Bidigare et al, 1989a). These latter observations are consistent with the results reported here. Further, it should be noted that a statistical analysis of chlorophyll $b$ and prasinoxanthin data collected at Stn 19 suggests that most (if not all) of the chlorophyll $b$ present was associated with prasinophytes and not prochlorophytes (Hooks et al. 1988). The distributional patterns exhibited by the cyanobacteria and eukaryotic ultraplankters (i.e. green monads) described here are similar to those reported by Glover et al. (1985) for the northwestern Atlantic Ocean.

Table 2. Phytoplankton growth rates and related parameters determined at Stn 19 (cast 37) using the chlorophyll a-labeling technique $\mathrm{C}_{0}$ : initial phytoplankton carbon concentration; $\mathrm{Chl}_{0}$ : initial chlorophyll a concentration; C:Chl: initial carbon-tochlorophyll a ratio; $\mathrm{dChl} / \mathrm{dt}$ : chlorophyll a synthesis rate; $\mu$ : growth rate. Incubations were performed for $24 \mathrm{~h}$ (sunrise-to-sunrise)

\begin{tabular}{|c|c|c|c|c|c|c|c|}
\hline $\begin{array}{l}\text { Depth } \\
(\mathrm{m})\end{array}$ & $\begin{array}{l}\% I_{0} \\
(\mathrm{PAR})\end{array}$ & $\begin{array}{l}\text { Photosynthesis } \\
\left(\mathrm{mgC} \mathrm{m}^{-3} \mathrm{~d}^{-1} \text { ) }\right.\end{array}$ & $C_{0}$ & $\mathrm{Chl}_{0}$ & $\begin{array}{l}C: C h] \\
(w: w)\end{array}$ & $\begin{array}{c}\mathrm{dChl} / \mathrm{dt} \\
\left(\mathrm{mgChl} \mathrm{m}{ }^{-3} \mathrm{~d}^{-1}\right)\end{array}$ & $\left(d^{\mu}\right)^{\mu}$ \\
\hline 5 & 29.0 & 25.82 & 14.79 & 0.284 & 52 & 0.115 & 1.01 \\
\hline 15 & 10.0 & 19.58 & 30.18 & 0.332 & 91 & 0.086 & 0.50 \\
\hline 44 & 2.0 & 20.50 & 6.62 & 0.664 & 10 & 0.604 & 1.41 \\
\hline
\end{tabular}


Despite the uniform photosynthetic rates observed in the upper $44 \mathrm{~m}$, there was a 3 -fold range observed in specific algal growth rates. The fact that the highest growth rate was measured near the base of the euphotic zone strongly suggests this green algae-dominated community was capable of rapid growth at low intensities of blue light. A similar conclusion was reached independently by Glover et al. (1985) and Wood (1985) for the eukaryotic ultraplankters observed in the northwestern Atlantic Ocean. This hypothesis has been supported by the recent laboratory experiments of Glover et al. $(1986,1987)$ who found that eukaryotic ultraplankters have greater photosynthetic and growth efficiencies than Synechococcus in the low intensities of blue-violet found near the base of euphotic zone. The exact causes for variations in growth rates measured at Stn 19 cannot be identified from the measurements performed in this study. Potentially, a number of factors could be responsible including differences in: (1) the availability of nutrients, vitamins and/or trace metals; (2) natural mortality rates (i.e. the presence of non-living pigmented cells); and (3) photosynthetically usable radiation (PUR).

In summary, the results presented provide descriptive evidence for a rapid succession of chromaticallyadapted phytoplankton during spring in the Sargasso Sea. This study extends previous observations which have examined time-dependent changes in 'bulk' phytoplankton parameters (e.g. chlorophyll concentration, primary production) during spring transition in the North Atlantic Ocean. Further studies are required to establish the linkages between phytoplankton pigmentation and the availability of spectral irradiance, and how they relate to depth-dependent variations in phytoplankton growth rate

Acknowledgements. For technical help, we are indebted to C. Green, D. Guffy, K. Heinemann, C. Johnson, J. Kitchen, and D. Menzies. For help with data analysis, we acknowledge S. Bernstein, S. Boztas and D. Siegel. This work was supported by the Office of Naval Research under the following contracts: N00014-85-C-0113 (R.R.B.), N00014-84-C-0132-IIA (J.M.), N00014-87-K-0084 (T.D.), N00014-84-K-0363 (R.I.), N00014$81-K-0383$ (H.P.), N00014-84-C-0382 (R.C.S.).

\section{LITERATURE CITED}

Bartz, R., Zaneveld, J. R. V., Pak, H. (1978). A transmissometer for profiling and moored observations in water. Proceedings of the Society of Photo-Optical Instrumentation Engineers, Ocean Optics V 160: 102-108

Bidigare, R. R. (1989). Photosynthetic pigment composition of the brown tide alga: unique chlorophyll and carotenoid derivatives. In: Cosper, E., Carpenter, E. J., Bricelj, M. (eds.) Lecture notes on coastal and estuarine studies. Springer-Verlag, New York (in press)

Bidigare, R. R, Morrow, J. H. Kiefer, D. A. (1989a). Derivative analysis of spectral absorption by photosynthetic pigments in the western Sargasso Sea. J. mar. Res. 47: 323-341

Bidigare, R. R., Schofield, O. Prezelin, B. B. (1989b). Influence of zeaxanthin on quantum yield of photosynthesis of Synechococcus clone WH7803 (DC2). Mar Ecol. Prog. Ser 56: $177-188$

Bidigare, R. R., Smith, R. C., Baker, K. S., Marra, J. (1987). Oceanic primary production estimates from measurements of spectral irradiance and pigment concentrations. Global biogeochem. Cycles 1: 171-186

Bienfang, P. K., Takahashi, M. (1983). Ultraplankton growth rates in a subtropical ecosystem. Mar Biol. 76: 213-218

Brown, O. B., Evans, R. H., Brown, J. W., Gordon, H. R., Smith, R. C., Baker, K. S. (1985). Phytoplankton blooming off the U.S. east coast: a satellite description. Science 229: 163-167

Campbell, L., Iturriaga, R. (1988). Identification of Synechococcus spp. in the Sargasso Sea by immunofluorescence and fluorescence excitation spectroscopy, performed on individual cells. Limnol. Oceanogr 33: $1196-1201$

Campbell, L., Carpenter, E. L., Iacono, V. J. (1983). Identification of and enumeration of marine chroococcoid cyanobacteria by immunofluorescence. Appl. environ. Microbiol. 46: $553-559$

Caron, D. A. (1983). Technique for enumeration of heterotrophic and phototrophic nanoplankton, using epifluorescence microscopy, and comparison with other procedures. Appl. environ. Microbiol. 46: 491-498

Deuser, W G. (1986). Seasonal and interannual variations in deep-water particle fluxes in the Sargasso Sea and their relation to surface hydrography. Deep Sea Res. 33: $225-246$

Dickey. T D. (1988). Recent advances and future directions in multi-disciplinary in situ oceanographic measurement systems. In: Rothschild, B. J. (ed.) Toward a theory on biological-physical interactions in the World Ocean. Kluwer Academic Publishers, Dordrecht, p. 555-598

Dickey, T D., Siegel, D. A., Boztas, S., Hamilton, M. K. (1986). Biowatt I - Multi Variable Profiler (MVP). University of Southern California, Ocean Physics Group Technical Report

Feldman, G., Kuring, N., Ng, C, Esaias, W., McClain, C., Elrod, J., Maynard, N., Endres, D., Evans, R., Brown, J., Walsh, S., Carle, M., Podesta, G. (1989). Ocean color: availability of the global data set. Trans. Am. Geophys. Un. $70: 634-641$

Fitzwater, S. E., Knauer, G. A., Martin, J. H. (1982). Metal contamination and its effect on primary production measurements. Limnol. Oceanogr. 27: 544-551

Foss, P., Guillard, R. R. L., Liaaen-Jensen, S. (1984). Prasinoxanthin - a chemosystematic marker for algae. Phytochem. 23: $1629-1633$

Gieskes, W. W. C., Kraay, G. W. (1986a). Analysis of phytoplankton pigments by HPLC before, during and after mass occurrence of the microflagellate Corymbellus aureus during the spring bloom in the open northern North Sea in 1983. Mar. Biol. 92: 45-52

Gieskes, W. W C., Kraay, G. W. (1986b). Floristic and physiological differences between the shallow and the deep nanophytoplankton community in the euphotic zone of the open tropical Atlantic revealed by HPLC analysis of pigments. Mar. Biol. 91: 567-576

Gieskes, W. W. C., Kraay, G. W., Nontji, A., Setiapermana, D., Sutomo (1988). Monsoonal alteration of a mixed and a layered structure in the phytoplankton of the euphotic zone of the Banda Sea (Indonesia): a mathematical analy- 
sis of algal pigment fingerprints. Neth. J. Sea Res. 22: 123-137

Glover, H. E., Keller, M. D., Guillard, R. R. L. (1986). Light quality and oceanic ultraphytoplankters. Nature, Lond. 319: $142-143$

Glover, H. E., Keller, M. D., Spinrad, R. W (1987). The effects of light quality and intensity on photosynthesis and growth of marine eukaryotic and prokaryotic clones. J. exp. mar. Biol. Ecol. 105: 137-159

Glover, H. E., Smith, A. E., Shapiro, L. (1985). Diurnal variations in photosynthetic rates: comparisons of ultraphytoplankton with a larger phytoplankton size fraction. J. Plankton Res. 7: 519-535

Guillard, R. R. L., Murphy, L. S., Foss, P., Liaaen-Jensen, S. (1985). Synechococcus spp. as likely zeaxanthin-dominant ultraplankton in the North Atlantic. Limnol. Oceanogr. 30 $412-414$

Hobbie, J. E., Daley, R. J., Jasper, S. (1977). Use of Nuclepore filters for counting bacteria by fluorescence microscopy. Appl. environ. Microbiol. 33: 1225-1228

Hooks, C. E., Bidigare, R. R., Keller, M. D., Guillard, R. R. L. (1988). Coccoid eukaryotic marine ultraphytoplankters with four different HPLC pigment signatures. J. Phycol. 24 $571-580$

Iturriaga, R., Marra, J. (1988). Temporal and spatial variability of chroococcoid cyanobacteria Synechococcus spp. specific growth rates and their contribution to primary production in the Sargasso Sea. Mar. Ecol. Prog. Ser. 44: 175-181

Jeffrey, S. W. (1974). Profiles of photosynthetic pigments in the ocean using thin-layer chromatography. Mar Biol. 26 $101-110$

Jeffrey, S. W. (1980). Algal pigment systems. In: Falkowski, P. G. (ed.) Primary productivity in the sea. Plenum, New York, p. 33-58

Latz, M. I., Frank, T M., Case, J. F., Swift, E., Bidigare, R. R (1987). Bioluminescence of colonial radiolaria in the western Sargasso Sea. J. exp. mar. Biol. Ecol. 109: 25-38

Laws, E. A., Redalje, D. G., Haas, L. W. Bienfang, P. K., Eppley, R. W., Harrison, W G., Karl, D. M., Marra, J. (1984). High phytoplankton growth and production rates in oligotrophic Hawaiian coastal waters. Limnol. Oceanogr. 29: 1161-1169

Lewis, M. R., Warnock, R. E., Platt, T (1985). Absorption and photosynthetic action spectra for natural phytoplankton populations: implications for production in the open Ocean. Limnol. Oceanogr. 30: 794-806

Lewis, M. R., Warnock, R. E., Platt, T (1986). Photosynthetic response of marine phytoplankton at low photon flux. In Platt, T., Li, W K. W. (eds.) Photosynthetic picoplankton. Can. Bull. Fish. Aquat Sci. 214: 235-250

Mantoura, R. F. C., Llewellyn, C. A. (1983). The rapid determination of algal chlorophyll and carotenoid pigments and their breakdown products in natural waters by reversephase high-performance liquid chromatography. Analytica chim. Acta 151. 297-314

Marra, J., Hartwig, E. O. (1984). Biowatt: a study of bioluminescence and optical varability in the sea. Trans. Am. Geophys. Un. 65: 732-733

Marra, J., Bidigare, R. R., Dickey, T D. (1989). Nutrients and mixing, chlorophyll and phytoplankton growth. Deep Sea Res. (in press)

This article was submitted to the editor
Menzel, D. W., Ryther, J. H. (1960). The annual cycle of primary production in the Sargasso Sea off Bermuda. Deep Sea Res. 6: 351-367

Menzel, D. W., Ryther, J. H. (1961). Annual vanations in primary production of the Sargasso Sea off Bermuda. Deep Sea Res. 7. 282-288

Murphy, L. S., Haugen, E. (1985). The distribution and abundance of phototrophic picoplankton in the North Atlantic. Limnol. Oceanogr 30: 47-58

National Academy of Sciences (1984). Global Ocean Flux Study. National Academy Press, Washington, D.C.

Norgard, S., Svec, W A., Liaaen-Jensen, S., Jensen, A., Guillard, R. R. L. (1974). Chloroplast pigments and systematics. Biochem. Syst. Ecol. 2: 3-6

Redalje, D. G., Laws, E. A. (1981). A new method for estimating phytoplankton growth rates and carbon biomass. Mar. Biol. 62: 73-79

Shapiro, L. P., Haugen, E. M., Keller, M. D., Bidigare, R. R., Campbell, L., Guillard, R. R. L. (1989). Taxonomic affinities of marine coccoid ultraphytoplankton: a comparison of immunochemical surface antigen cross-reactions and HPLC chloroplast pigment signatures. J. Phycol. 25: $794-797$

Smith, R. C., Baker, K. S., Dustan, P. (1981). Fluorometric techniques for measurement of oceanic chlorophyll in the support of remote sensing. Ref. 81-17, Scripps Institution of Oceanography, La Jolla, California

Smith, R. C., Bidigare, R. R., Prézelin, B. B., Baker, K. S., Brooks, J. M. (1987a). Optical characterization of primary productivity across a coastal front. Mar. Biol. 96: 575-591

Smith, R. C., Booth, C. R., Star, J. L. (1984). Oceanographic bio-optical profiling system. Appl. Opt. 23: 2791-2797

Smith, R. C., Brown, O. B., Hoge, F. K. Baker, K. S., Evans, R. H., Swift, R. N., Esaias, W. E. (1987b). Multiplatform sampling (ship, aircraft and satellite) of a Gulf Stream. warm core ring. Appl. Opt. 26: 2068-2081

Smith, R. C., Prézelin, B. B., Bidigare, R. R., Baker, K. S. (1989) Bio-optical modeling of photosynthetic production. Limnol Oceanogr. (in press)

Stauber, J. L., Jeffrey, S. W. (1988). Photosynthetic pigments in fifty-one species of marine diatoms. J. Phycol. 24 $158-172$

Strickland, J. D. H., Parsons, T R. (1972). A practical handbook of seawater analysis, 2nd edn. Bull. Fish. Res. Bd Can

Welschmeyer, N. W., Lorenzen, C. J. (1984). Carbon-14 labelling of phytoplankton carbon and chlorophyll a carbon determination of specific growth rates. Limnol. Oceanogr 29: $135-145$

Whitledge, T E., Malloy, S. C., Patton, C. J., Wirick, C. D (1981). Automated nutrient analyses in seawater. Department of Energy and Environment, Brookhaven National Laboratory, Upton, New York (BNL) 51398

Whitledge, T E., Bidigare, R. R., Zeeman, S. I., Sambrotto, R N., Roscigno, P. F., Jensen, P. R., Brooks, J. M., Trees, C., Veidt, D. M. (1988). Biological measurements and related chemical features in Soviet and United States regions of the Bering Sea. Cont. Shelf Res. 8: 1299-1319

Wood, A. M. (1985). Adaptation of photosynthetic apparatus of marine ultraphytoplankton to natural light fields. Nature, Lond. 316: 253-255

Manuscript first received: July 11, 1989

Revised version accepted: October 26, 1989 